\title{
Nation Building and Social Values in Nepal
}

DOI: https://doi.org/10.47175/rissj.v2i1.173

\begin{abstract}
| Tara Nath Ghimire ${ }^{1}$ | Amrit Kumar Shrestha² | Shyam Prasad Phuyel ${ }^{3}$ |
${ }^{1}$ Lecturer, Political Science, Ratna Rajyalaxmi Campus, Kathmandu, Tribhuvan University, Nepal

${ }^{2}$ Associate Professor, Political Science Education, Central Department of Education, Kirtipur, Tribhuvan University, Nepal

${ }^{3}$ Lecturer, Political Science Education, Central Department of Education, Kirtipur, Tribhuvan University, Nepal

${ }^{1}$ taraghimire267@gmail.com

2amrit365@gmail.com

3shyam.phuyal@cded.tu.edu.np

ABSTRACT

Social norms play an important role in the state-building process. If the time of formation of Nepal is considered as the period of unification, then some important facts regarding the formation of the state of Nepal and the structure of the society here can be recounted. Regarding the formation of the nation-state, the structure of the Nepali state, and the position of the Nepali society are not of the same nature. From the pre-unification states of Limbuwan, Khumbuwan, Kirat, Khas, Baisi, Chaubisi, Shen, etc. to the restructuring period of the state, the state structure has not been formed in the recognition of the nation-state. Because the small and big states before unification were states built on power. Due to power, the great form of the Gurkha state had built a unitary Nepal. There is not general recognition of the statebuilding process of the nation-state. In the same way, even when restructuring the state, that recognition was not accepted. The foundations of federal-state formation, such as language, religion, and the basis of equality and plurality of the population, were also not accepted, which is a form of recognition of the nation-state. In such a situation, this article attempts to study a state-building and social tradition which is already coming together in Nepali society. KEYWORDS

caste; language; society; value; traditions
\end{abstract}

\section{INTRODUCTION}

The recognition of the nation-state is based on social values and norms. The state system before the religious reform movement can be re-established based on social values. The establishment of a unitary state is a country built based on state power. The basis of Nepal's construction was considered to be a powerful king. King Prithvi Narayan Shah, under the guise of power, merged the small kingdom into the then Gurkha kingdom. "At that time, Nepal's borders seemed to extend from the Tista in the east to the Satalaj, in the west, the Himalayas in the north, and the Ganges in the south" (Basnet, 1971, p. 80). History can be traced back to the unification of Nepal to prevent King Prithvi Narayan Shah from the then imperialism of the British. Looking at the composition of the small states before unification, the basis for the initial formation of those states seems to be based on social values.

Apart from unification, the new territory received as a gift from the UK is also in the territory of today's Nepal. After this, the borders of Nepal were added as Banke, Bardia, Kailali, and Kanchanpur as a new region under the Rana Prime Minister Junga Bahadur. King Prithvi Narayan Shah had implemented the Hindu tradition and spread the culture of the Gorkha state in the whole country, although all the smaller states united within this border had their customs and rituals. After establishing the capital in Kathmandu, the traditions of the Newars were given more importance. That culture continues even in the democratic era, but since the establishment of the republic, importance has been given to other local cultures and rituals. However, "evidence of the development of Kirat civilization and culture has been 
found in this region since about 700-800 years before the time of unification" (Acharya, 2007, p. 57). Although when the Shah period came to the Panchayat system during the Rana period, the Hindu customs didn't change, while in the Republican period, attempts were made to give place to the social beliefs of other cultures too.

According to Mahajan (1988) "The main basis of nation-building is language, culture, and tradition. Sovereign states have gradually been formed based on similar nations which contracted a certain natural territory into nationality" (p. 272). This is how modern states are built? The formation of the state of Nepal was normal in this way. The pre-unification state of Nepal and the restructuring of the state in the democratic era were built on the same premise. However, the restructuring of federalism was done only out of the political will. "The whole endeavor of European civilization was one people, one territory and one nation, and the goal of the people was a unitary territory" (Elazar, 2008, p. 223). It is on this basis that the monarchy and the powerful unitary state have been born. The modern state is built on a unitary nature. The process of building the state of Nepal has the same basis. In this article, an attempt has been made to explain the relationship between state-building and the practice tradition from the time of the unification of Nepal to the present-day state structure.

\section{RESEARCH METHODS}

The study has analyzed the national building and social values in Nepal here. The main objective of the study is to break down the relationship between customs and traditions in the state-building process. Traditions, religions, and culture also play a role in nationbuilding. Studies have been based on these topics. To reach a conclusion, descriptive and analytical methods have been adopted. In this study, only secondary data is used to get the conclusion. The data has been collected through the library. Other approaches have also been used in inappropriate places as required.

\section{RESULTS AND DISCUSSION}

\section{The Social Edict}

The structure of Nepali society is very mixed. Ethnicity, religion, and complex geography are the hallmarks of Nepal. After the restoration of democracy, issues of particular caste have come to the fore in Nepali politics. Ethnicity is an issue related to caste. Ethnicity is a means of identity. Any caste is a different matter from the geographical boundaries of the state because any ethnic issue is closer to the nation than to the state. A nation is a cultural concept. It has no political geography. In the world, castes are classified by color, religion, and region.

Nepal is also a multi-ethnic country. Nepal is one of the most ethnically diverse countries in the world. In any country with ethnic diversity, if any castes, classes, and communities are governed by other classes or communities, then the issue of ethnicity comes to forward. This issue has come forward politically in Nepal since the restoration of democracy. The issue of ethnicity has gained importance in Nepal when it comes to constitution drafting and state restructuring. The issue of ethnicity has come forward in Nepal as the government is governed based on a single cultural tradition within a diverse cultural structure.

The caste system divided in Nepal is based on Hindu philosophy. "Concerning Nepal, caste and Hinduism is a hierarchical system. In Nepal, using caste and ethnicity in the same sense has also created confusion. Caste is a social system determined based on birth. Ethnicity is a community that speaks the same language and has the same culture, identity, economic and social life" (Shiwakoti, 2013, p. 368). Based on the new research found in Nepal, it has been found that there are currently 125 castes/ethnicities in Nepal. According to the 2011 census of the Central Statistics Office, there are 125 castes in Nepal and 130 
castes including five other castes. Among the 125 castes, there are five more ethnic figures, including two foreigners (CBS, 2013, p. III). According to the CBS 2011 census, Chhetri is on the list of the largest castes in the country followed by Brahmins (Hilly).

Looking at the political history of Nepal, it is found that there is a tendency to maintain social order by dividing work based on caste and caste system. But cast and ethnicity of Nepal are being developed due to the easiness of the geographical structure. Gurung (2012) found that;

The Mongols, in search of a new place, moved towards west and south, and the Aryans headed towards north and east in search of a new place. They met each other for the first time in the Gandaki region of Nepal. Mangols of Gandaki spread towards the east and started living in Tibet, the Himalayan region, inner terai, and the plain region of Brahmaputra. On the other hand, the Aryans of Gandaki spread not only in the Bharatkhand plain but also in Kashmir, Kangra, Garhwal, Kumaon, and Karnali region. Sometimes, based on power, some castes have gone far beyond their community. (pp. 214-215)

These facts of history were also created based on the early social structure of Nepal, which seems to be in line with the fact of building a primitive society. "Various researches had been done on the old caste and ethnicity of Niall. Based on civilization, need and compatibility, the community started to gather and develop at a particular place. The status of the first settler of the old caste in Nepal cannot be ascertained based on evidence" (Adhikari, 2011, p. 12). But Baburam Acharya has said "The sociologists of the present day, has named this caste Astro-Asian or fiery foreigner and has considered the same caste to be the primitive native of this region (Acharya, 2011, p.12).

Since the ancient history of the appropriate, it is found to have a multi-ethnic settlement in Nepal. It is seen that the various reforms made during the reign of King Jayasthiti Malla and the reforms of King Ram Shah have to lead to managing the customs of the social structure in an ethnically populated. King Jayastiti Malla had brought various reforms too. Among those, social reform has a long-lasting effect till now. The tradition of dividing class and caste and the practice of dividing work according to the same division along with its effect have remained till today. According to his division of castes and classes, Nepal's society was divided into 4 classes and 36 castes. There were Brahmins, Chhetri, Vaishya, and Shudra in 4 classes. Brahmins were also divided into two castes named Panchgaud and Panch Dravid. Brahmin is to worship gods and goddesses along with a high level of work, Chettri is to do political and administrative works, Baisya is to do trade, Sudra is to do agricultural works. In this way, the division of work was between 4 classes was divided. For Brahmins and Chhetris, the rules of Brahmacharya, Grihastha, Vanaprastha, and Sanyasa Dharma were followed according to their age in social life. Other classes were divided into 64 castes.

Similarly Yadav (1985) found that;

In Newar society, Acharya, Vaidya, Daivajna, and Shrestha were considered to be of the highest standard. Acharya was divided into three classes, Vaidya into four classes, Daivajna into four classes, and Shrestha into several classes. Only the 10 Newars of the Shrestha and the above mentioned three castes (except sudra) were given the right to wear the Yajna. Again the Jyapu caste of the Newar community was divided into 32 sub-castes. The system where the top four classes were prohibited from using the things touched and used by the lower castes. The water of Upper Lor Sharmakar etc. could not continue. People from upper castes were banned from eating and drinking by lower castes. It was customary to show due respect to the upper castes. (p. 18) 
After the restoration of democracy, questions arise about this subject. The effect of the customs called by King Jayasthiti Malla is still in an important place. Despite many questions in the customs, our social plans and structures are still bound by the rules of those Hindu customs.

King Ram Shah of Gorkha also made many reforms. Ram Shah was the king of Gorkha. The social impact of administrative reform is still there. "According to the rules made by him, if a member of the dynasty kills someone he/she would be expelled from the country. Similarly, Brahmin, Sanyasi, Bairagi, and Bhat would also be expelled from the country if he/she kills someone. But if member ber Khas, Magar, Newar, etc. and other castes kill someone he/she would get death" (Yadav, 1985, p. 36). The base of the reforms made by Ramshah is also found to be ethnicity. In his reforms, the condition of measurement has remained the same till today, while the effect of religious reform has become even more profound. Customs such as protection of cow, construction of deity temples, service to the wallet, and porter are the customs implemented by Ram Shah. These religious activists are still active in Nepali society. When the people of the palace died, the tradition of playing long instruments was practiced by Jayasthiti Malla.

The reforms of these kings played an important role in the social and cultural structure of Nepali society. As Nepali laws are customary laws, some of today's laws are following the values of that time. The reforms of Jayasthiti Malla and Ramshah were based on Hindu philosophy and the same psychology. These issues may be the subject of research, but those reforms have not only advocated Hindu philosophy to this day but have also developed some good rites. After the restoration of democracy, those customs and Hindu philosophy have been badly affected. Looking at the history of the Shah Period and the Rana Period, there was a Hindu philosophy-based system of governance. These values are no longer confined to any caste or place. This reality has added a challenge to Nepal's new state structure.

After the event of 1960 A.D, King Mahendra implemented the old system of the Shah Dynasty bases on Hindu philosophy. "However, in 1970, lower castes started to protest against the Brahmins. During the Panchayat rule, attempts were made to bring together Sherpas, Tamangs, Magars, Gurungs, Rais, and Limbus in the name of Setamgurali. After that organization of Dalits was established for politics" (Neupane, 2000, p. 82). Ethnic issues have entered the mainstream of politics in Nepal since the 1990s. "Ethnic politics rose in Nepal's politics. In 1990, caste rights were neglected in the core issues of politics. After a period of long demands and struggles, in the transformation of 2006, they changed the absolute state of the Hindus" (Hagen, 2012, p. 2). Despite many struggles, there have been some changes in the law, but the pressure of Hindu philosophy on the society is deepening as its value recognition is increasing.

Even after the incident in Nepal in 1990, democratic rule including the king was implemented. Even in this situation, the regime based on Hindu philosophy was continued. The 1990 constitution had made a constitutional provision not to discriminate based on caste. Accordingly, it was mentioned that special services will be provided to those who are backward due to economic, social, and educational problems and not based on caste. This belief was also protected in the directive principle of the state.

The Interim Constitution 2007 was a constitution with the involvement of the Maoists. The Constitution also made arrangements to eliminate caste discrimination and punish those who discriminate. According to the same constitution, a policy was implemented in Nepal to include the backward castes, genders, and classes in government services, including politics. From the time of unification in Nepal to the time of the republic, Hindu philosophy has influenced the rule of Nepal. The reins of politics also seem to be held by the upper class under Hindu influence. In this context, Bhattachan (2008) also said, "Changes have come, 
people's movements have come, political systems have come and gone, political leaders have come, the monarchy has come but one language (Khas Nepali), one religion (Hindu), one culture (Hindu), One gender (male), one class (higher) and one region (mountain) have always been the same" (p. 22). If these issues are brought to light in the wake of the restoration of democracy, the people's movement has worked to improve the situation. In the last forty years, the state of ethnic presence in Nepal's politics. The analysis done by Hark Gurung is included in this table.

Table 1. Ethnic presence in politics

\begin{tabular}{lllll}
\hline Caste & $\mathbf{1 9 5 9}$ & $\mathbf{1 9 7 8}$ & $\mathbf{1 9 8 1}$ & $\mathbf{1 9 9 1}$ \\
\hline Hilly Group & 78.0 & 85.0 & 79.5 & 79.0 \\
Brahmin & 25.5 & 21.3 & 12.5 & 36.6 \\
Chhetri & 31.2 & 36.2 & 36.6 & 18.5 \\
Newar & 3.7 & 7.9 & 8.0 & 6.8 \\
Tribes & 15.6 & 18.9 & 22.3 & 13.3 \\
Occupational caste & 0.0 & 0.8 & 0.0 & 0.5 \\
Terai Group & 22.0 & 15.0 & 20.5 & 21.0 \\
Brahmin & 2.6 & 2.3 & 0.0 & 2.4 \\
Vumihar & 10.1 & 7.3 & 7.1 & 5.4 \\
Baaniya & 2.8 & 1.6 & 1.8 & 2.0 \\
Tribes & 3.6 & 3.2 & 9.5 & 8.8 \\
Muslim & 1.8 & 0.8 & 1.8 & 2.4 \\
\hline Total & 100 & 100 & 100 & 100 \\
\hline Seat numbers & 109 & 127 & 112 & 205 \\
\hline
\end{tabular}

Note. Data extracted from Neupane, 2000, p. 173

In the era of democracy, a lot of work has been done on political participation from the Nepali ethnic and regional levels. They have also raised the grounds for restructuring the state in Nepal. The reason for this discrimination is said to be the armed insurgency started by the CPN-Maoist in 1996. 'In the first pamphlet of the People's War, issued on February 13, 1996, he mentioned the need to protest against the domination of one religion, language and ethnicity'. He had raised the issue of caste in his 40-point demand submitted to the then government on January 19, 1996. At point no.20 'All must end ethnic exploitation and oppression, and establish ethnic rule in tribal-dominated areas' is said. But a '12-point memorandum of understanding between the leading Political Parties and the Communist Party of Nepal-Maoist (CPN-Maoist) on 22 November 2005, focused on a ceasefire for the monarchy and the establishment of full democracy. Ethnic inequality and regional inequality do not seem to be the main topics in the letter. In the letter of understanding, it was not agreed that the state would be restructured into federalism. In the preamble of the memorandum, it was mentioned that progressive restructuring of the state would be done to solve the class, ethnic, gender, regional, and other problems of political, economic, social, and cultural sectors by establishing a complete democracy like the autocratic monarchy'.

After the end of the Maoist armed conflict. The restrictive clause of Article 13 (3) of the Interim Constitution, drafted on January 15, 2007, stated that special provisions would be made by law for the empowerment or development of the backward classes, including the Dalit Adivasi Janajati.

Similarly, under the right to equality in the constitution, Article 21 provided for the right to social justice and the backward class would have the right to participate in the structure of the state based on the principle of proportional inclusion. This provision established the right of all castes to participate in all organs of the state as a fundamental right. Article 25 (14) of the state policy of the constitution mentioned those special arrangements would be 
made for such individuals and communities. Based on this provision, an inclusive system has been implemented by making provisions in the law for the number of posts in the state organs including public service. In Article 7 (7) of the Second Amendment to the Civil Service Act (1992), to make the civil service inclusive, a new provision was made for fortyfive percent of the posts to be filled through open competition for Adivasi Janajati, Madhesi, Dalit disabled people and women and rule 11 (a) of the Service Commission Rules 1998, also provided for inclusion in the education service on the same basis. This provision was further amended from the back,'(Nepal Law Commission, 2014, 2014-03-11).

Article 142 of the Interim Constitution of 2007 provided the system where political parties should adopt an inclusive system when registering parties (Article 142 (3) c). Even after the changes of 1990, the presence of Janajatis and backward classes in government posts in Nepal is not good. The Interim Constitution of 2007 has tried to address that. Here is a table of the situation of the Janajati and backward classes in the government service at that time. The following is the list of candidates for the post of Branch Officer of the Government of Nepal conducted by the Public Service Commission in 1998 and its results.

Table 2. Public service commission result

\begin{tabular}{lll}
\hline Social groups & Petitioner \% & Passed \% \\
\hline Brahmin & 65.5 & 67.6 \\
Chhetri & 17.4 & 15.5 \\
Newar & 8.4 & 7.9 \\
Others (Including Madhesi) & 4.9 & 5.2 \\
Hilly castes (7) & 3.7 & 3.4 \\
Muslim & 0.2 & 0.4 \\
\hline Total & 100 & 100 \\
\hline
\end{tabular}

Note. Data extracted from Gurung, 2012, p.130

In the first Constituent Assembly election since the drafting of the 2007 Interim Constitution, the political parties had given priority to the issue of caste discrimination in their manifestos. Nepali Congress had raised the issue of "Making ethnic identity resultoriented" (Nepali Congress, 2008, p. 2), while the CPN-UML had raised the issue of "Taking Multi-ethnicity as an important basis" (Nepal communist party, UML, 2008, p. 11), whereas, the CPN-Maoist had raised the issue of "ending ethnic oppression," in their respective manifestos.

Other political parties have also called for an end to caste discrimination in their manifestos. These issues were also mentioned by all the political parties in their manifestos in the second election of the Constituent Assembly.

Based on these ethnic facts and analysis, one of the foundations of the federal system, ethnicity, has come forward. The proposal to take the state in a federal structure while restructuring has come up in national politics. In this context, the Pattern proposals for research and treaty have come to the fore from various intellectual fields, both institutionally and personally. In this regard, various research studies and proposals for federalism on institutional and individual visas have come forward from various intellectual fields. Proposals for the framework of federalism were presented for the new nation-building process.

The demands of the Maoist insurgency were also a matter of caste and place. Even the task of restructuring the state, which was hired to end that insurgency, has failed to capture the basic foundations of state and nation-building. There were two main reasons for this. The first is the dominance of politics in the restructuring; the second is the indelible influence of Hindu philosophy. 


\section{Social Tradition}

Nepali society is a society based on ancient Hindu philosophy. Looking at the political movements in Nepal, it is found that they were focused on human rights and democracy. After the restoration of democracy, a state system of a character different from the traditional values was introduced in Nepal. This has been further exposed by the Maoist movement. Along with the restoration of democracy, political tradition and its basis have also been explored in Nepal. Even at that time, politics and social tradition were found to be moving together in the prehistoric rhythm. Nepal's political tradition has been associated with a certain religion. This rule has become a priority in the democratic era as the rule of Nepal has been affected by the tradition based on Hinduism and most of the laws of Nepal have been based on that tradition. Discussions have started on the impact of religion and tradition, which has been going on for a long time, regarding state operation and state reconstruction.

Democratic Constitution of the Kingdom of Nepal in 1990 did not recognize secularism. The Constitution defined the Kingdom of Nepal as "a multi-ethnic, multi-lingual, democratic, independent, indivisible, sovereign, Hindu constitutional monarchy" (Article 4 (1)). In the post-democratic period, which was achieved after a long struggle and sacrifice, Nepal was governed by a system based on absolute Hinduism, but other religions were also free to practice their religion. That provision of the constitution had maintained the Hindu tradition of Nepal since the time of unification.

Since the unification of Nepal, Prithvi Narayan Shah had ruled in a unitary state system based on the rules of Hindu tradition. The continuation of this practice was broken by the 2007 Interim Constitution, which was drafted in the peace process after the Maoist rebellion. The Interim Constitution of Nepal 2007 defined Nepal as an independent, indivisible, sovereign, secular, inclusive, and fully democratic state (Article 4 (1)). According to this definition, Nepal has become a secular state after the end of the state based on the Hindu tradition of unification. Rashtriya Prajatantra Party Nepal has been protesting against this announcement since then, whereas Hindu organizations, including the World Hindu Federation, have been staging protests. Despite the reforms in the democratic norms, those steps were not taken in a democratic process because; there was no excess of public opinion on the issue of state structure and religion.

In Nepal, non-Hindu communities had traditionally been protesting against the prohibition of anything other than Hinduism. "At that time, the MNO had shown two reasons for not adopting Hinduism, The first is to establish its existence in the local body and to overcome Hindu domination, and the second is to accept the ethnic identity of the Mongols who are about to be wiped out by the Hindus at the local level" (Hagen, 2012, p. 138). In addition to the Mongols, many racist organizations were open at the time. The organizations have recently joined the National Tribal Federation.

According to the latest statistics taken in Nepal in 2011, there are 10 different religions in Nepal, including Hindu, Buddhism, Islam, Kirat, Christianity, Nature, Bon, Jainism, Bahai, and Sikhism religions. It has the largest number of followers of Hinduism. Hindu traditions are practiced by 81.3 percent of the total population of Nepal. In the second period of democracy, conversion of religion based on ethnicity seems to have been adopted. But how much religion has to do with politics in Nepal, which religion has affected political development? No research has been done on this subject. No factual research has been done on the subject of religion, tradition, faith, or politics. The population-based on the number of religions in Nepal is listed below.

Although proselytizing is said to have been created in protest of the long-standing Hindu traditional monopoly, the fact remains that the presence of all classes and communities in politics and all state bodies has diminished. Although the number of Hindus has decreased 
in terms of religion based on the old statistics, the number of Hindus seems to have increased based on the latest census which is placed in the following table:-

\begin{tabular}{lll}
\multicolumn{3}{l}{ Table 3. Situation of religious followers in Nepal } \\
\hline Religions/Year & $\mathbf{2 0 0 1}$ & $\mathbf{2 0 1 1}$ \\
\hline Hinduism & 80.6 & 81.3 \\
Buddhism & 10.7 & 9.0 \\
Islam & 4.2 & 4.4 \\
Kirant & 3.6 & 3.1 \\
Christianity & 0.5 & 1.4 \\
\hline
\end{tabular}

Note. Data Source, Tamang, 2007, p. 63.

Although the facts show that the followers of Hinduism, Muslim, and Christianity have increased in the 10 years, "the number of people following the Hindu religion was 81.3 percent" (Khanal, 2007, p. 187). A study of this overall period shows that the size of Hinduism in Nepal has decreased and the number of followers of other religions has increased. The lack of ethnic, regional, and gender equality in Nepal's development along with the open political environment in Nepal since 1990, and the main reason for this is believed to be the influence of the Hindu tradition on the politics of demand. However, based on which religious tradition and what is the impact on development? The impact of tradition on development and the impact of other religions and Hinduism on development can be researched and researched but Nepali laws, political culture seems to have grown in Hindu tradition. The analysis that the multitude at the center of politics is lagging behind the pace of equality, development in the country in the face of this Hindu tradition has led to criticism of Hinduism. Religion, tradition, and their interpretation, use, and effect remain to be seen. Hindu traditions and other traditions have been discussing their kind of struggle. Especially in this work section, it is a fact that Hindus and other religions are aware of their religion. There is no research on how any tradition and the culture it carries have an impact on politics. But there is a situation where among non-Hindus, Hindus are being publicly exploited. Here is the schedule submitted by Krishna Bhattachan that there is a dispute between non-Hindus and non-Hindus.

Table 4. Hinduism against Islam, Christianity, and other religious groups

\begin{tabular}{ll}
\hline Opposition & Favoring side \\
\hline Democracy & Federal Republican Democracy \\
Unitary state & A separate identity of religion \\
Hindu hegemony & Religious tolerance \\
Buddhism is a part of Hinduism & Secularism \\
Registration Shiv Sena as a political party & Equality of all religions based on constitution and law \\
Directly and indirectly, discourage deep Hindu: & Positive action towards discrimination \\
So-called National Statistics & Factual realistic national statistics \\
\hline
\end{tabular}

Note. Data Source, Bhattachan, 2008, p. 61.

This kind of analysis of Hindus by non-Hindus does not seem to be based on facts. Because none of the Hindus are followers of monarchy, followers of the unitary state, discourage other religions, enjoy illusions. Even within the political parties based on tradition and caste, the Janajati and Dalit fraternal organizations have also come to terms and the issue of state restructuring has come forward. The fraternal organizations of Janajatis and Dalits have also joined the political parties based on tradition and caste and the issue of state restructuring has come to the fore. 
The dominance of the Hindu tradition was also said to be one of the reasons for the Maoist people's war that lasted for ten years. In its first pamphlet, dated February 13, 1996, stating the need for a people's war, it was stated that 'one religion dominates'. Whereas in his commitment letter based on the right of regional self-determination and autonomy, the current unitary form of the state will be restructured and the state will be restructured into a federal structure (Maoist, 2008, p. 12).

Among the various obstacles to development and equality, the Maoists had made Hinduism the mainstay among other obstacles. Similarly, the CPN (UML) in its manifesto of the Constituent Assembly in 2008 has stated that religion is one of the reasons for ending all existing discrimination such as gender, ethnic, regional, linguistic, and religious as social oppression (UML, 2008, p. 10). The Nepali Congress, by considering all religions, cultures, and regional diversity as the heritage of the Nepali nation, expressed its commitment to materialize the demands from those regions through the constitutional process (Nepali Congress, 2008, p. 11).

The Mazdoor Kishan Party should be allowed to practice religion according to its beliefs. The Madhesi Janadhikar Forum has mentioned that even though the structure of Terai is based on Hinduism, in reality, it is multi-religious and Nepal should be kept secular. Thus, religion has been made one of the main pillars of state restructuring. Among the parties represented in the Constituent Assembly, R.P.P., (Nepal) has only demanded a referendum on the creation of the Hindu state. He has maintained the same demand in the Constituent Assembly (Second). Even within the Nepali Congress, there is no complete consensus on secularism, however, in its partisan views; it is in favor of secularism.

Nepal's political tradition and its basis are being explored concerning the drafting of Nepal's constitution and state restructuring. In a country inhabited by many tribes, it is common to discuss the issue of governance based on religious traditions. From the time of unification to the republican period, there were many movements in Nepal. Although Nepal has always been successful in the campaign for democracy, public opinion has not been appreciated in the context of religion and culture in Nepal, because no referendum has been held on these issues. Decisions that are driven by the will of the political leadership and international influence may not stabilize the process of state formation.

\section{CONCLUSION}

From the time of unification to the time of the republic, there have been two types of movements in Nepal. One movement was about democracy, while the other movement was focused on the rights of some castes. After the restoration of democracy, this issue got some recognition. The Maoist movement compared the religion and culture of the castes with the state-building process there is some accommodation behind the integration of caste and culture. After the rise of democracy, some provisions were added to the constitution. The dissolution of the Maoist movement and the interim constitution drafted to bring it into the mainstream of politics was the main document of state-restructuring. The constitution drafted after that is an attempt to restructure Nepal based on nation-building. Although the basis for the formation of solidarity and the basis for nation-building is the same, the new structure of the republic has not been in line with it since the unification period in Nepal. Politics and social values have played a vital role in this. Hindu influence was growing in Nepal, which was built on the side of power, while political and foreign influence had worked in the restructuring of the state. However, the general principles of state-building have been obscured. On the other hand, the long-standing Hindu influence has created a unitary nature throughout the country. These factors have added complexity to the state restructure of Nepal. 


\section{REFERENCES}

Acharya, B. (2007). Prachin Nepal [Ancient Nepal]. Kathmandu: Antarastriya Manch Chhapakhana Prali.

Basnet, L. S. (1971). Nepal Rastrako Yeitihasik Jhalak [Historical glimpse of Nepal]. Biratnagar: Nepali Sahitya Bhandar.

Bhattachan, K. (2008). Minorities \& indigenous peoples of Nepal, Kathmandu: National Coalition Against Racial Discrimination.

Central Bureau of Statistics (2012). National Population and Housing Census 2011. (National report). Kathmandu: Author.

Central Bureau of Statistics (2012). National Population and Housing Census 2011. (Village Development Committee/Municipality). Kathmandu: Author.

Central Bureau of Statistics (2013). National Population and Housing Census 2011. (Cast/Ethnicity \& Language). Kathmandu: Author.

Nepali Congress (2007). Sambidhanshabha nirbachan ghosanapatra [Manifesto of election of Constituent Assembly]. Kathmandu: Author.

Elazar, D. (2008). Exploring federalism. Alabama: University Press of Alabama.

Gurung, H. (2012). Nepal Adhirajyako Banaut [Structure of Kingdom of Nepal]. In B. Thapa (Ed.), Bishay Bibid [Miscellaneous subjects], (pp. 224-227). Kathmandu: Himal Kitab Prali.

Hagen, S. (2012). The Ethnic politics in Nepal Democracy in the margins. London and New York: Rutledge Taylor \& Francis Group.

Khanal, K. (2007). Rajyako Puna samrachana Yek Prastav [A proposal of state restructuring]. S. Tamang (Ed.), Nepalko sandharbhama rajya Punasamrachana [Staterestructuring in reference of Nepal], (pp. 185-218). Kathmandu: Samana Prakashan.

Mahajan, V. D. (1988). Political theory. New Delhi: S. Chand \& Company Ltd.

Maoist, CPN. (2007), Sambidhanshabha nirbachan pratibaddatapatra [Commitment letter of election of Constituent Assembly]. Kathmandu: Author.

Nepal Majdur Kisan Party (2010). Nepal Majdur Kisan party ko Pratibedan [Reporto of Nepal Majdur Kisan Party]. Kathmandu: Author.

Nepal Sarkar. (2007). Nepal ko antarim Sambidhan 2063 BS [Interim constitution of Nepal]. Kathmandu: Nepal Sarkar Kanoon Kitab Byabastha Samiti.

Nepal Sarkar (2015). Nepalko Sambidhan [Constitution of Nepal]. Kathmandu: Nepal Sarkar Kanoon Kitab Byabastha Samiti.

Neupane, G. (2000). Nepalko jatiya prasna, samajik banut ra sajhedariko sambhabana [Issues of caste, social structure, and probability of sharing in Nepal]. Kathmandu: Center for Development Studies.

Siwakoti. G. (2013). Pahichan ra darshanko sankatma Nepalko rajnitik byabastha [Nepalese political system in identical and philosophical distress]. Kathmandu: Pairabi Prakashan.

Tamang, P. (2007). Loktantra ra rajyako punasamrachana: Aawasyakta, awadharana ra prarup [Democracy and re-structuring of state: Necessity, concept, and outline]. S. Tamang (Ed.), Nepalko sambandhama rajya punasamrachana [State re-structuring in regarding of Nepal] (pp. 57-84). Kathmandu: Samana Prakashan.

UML. CPN (2007). Sambidhanshabha nirbachan ghosanapatra [Manifesto of election of Constituent Assembly]. Kathmandu: Nepal Communist Party UML.

Yadav, P. L. (1985). Nepalko rajnitik itihas [Political history of Nepal]. Rajbiraj: Mahanthi Yadav. 